\title{
Phytoplankton and Zooplankton Diversity and Water Quality Assessment of Three Ponds in Hooghly District (West Bengal, India)
}

Soudip Karmakar ( $\square$ soudip.karmakar.1@gmail.com )

Ramakrishna Mission Vivekananda Centenary College, Rahara, Kolkata- 700118

\section{Research Article}

Keywords: Phytoplankton, Zooplankton, Physicochemical parameters, Shannon-Wiener Index, Simpson dominance index.

Posted Date: February 25th, 2021

DOI: https://doi.org/10.21203/rs.3.rs-256542/v1

License: (a) (i) This work is licensed under a Creative Commons Attribution 4.0 International License.

Read Full License 


\title{
Phytoplankton and Zooplankton Diversity and Water Quality Assessment of Three Ponds in Hooghly District (West Bengal,India)
}

\author{
SOUDIP KARMAKAR
}

February 18, 2021

\author{
Department of Zoology, Ramakrishna Mission Vivekananda Centenary Col- \\ lege, Rahara, Kolkata-700118 \\ [*]Author's Mail Id : soudip.karmakar.1@gmail.com \\ [*]Institutional Mail Id : rkmvccollege@rkmvccrahara.org
}

\begin{abstract}
The present study focuses on the Phytoplankton and Zooplankton Diversity and Water quality assessment of three ponds in Hooghly District using the physiochemical and biological parameters, with due consideration to the Planktonic species. The study was carried out during the Spring and Summer season for a period of two months from 28th March to 28th July, 2020. The pollution levels of the ponds were determined with the help of Palmer's Indices and were further supported by the physicochemical parameters. The Plankton assessment (qualitative) was associated with the physicochemical parameters like $\mathrm{pH}$, TDS, EC, Calcium, Chlorides, Dissolved Oxygen, Phosphates, Nitrates, Bromides and Nitrites. Each pond are a well-managed fishpond,showed and Highest Shannon-Wiener Index diversity value 1.917, contaminated with organic waste matter, from adjacent cattle sheds, show higher Zooplankton abundance.
\end{abstract}

Keywords - Phytoplankton, Zooplankton, Physicochemical parameters, Shannon-Wiener Index,Simpson dominance index.

\section{Introduction :-}

Ponds are closed microcosms and it is not an easy system to evaluate, as they present great internal complexity. Unlike ponds are smaller in size and less in depth. Therefore, ponds maintain a unique freshwater ecosystem, providing an unparalleled ecosystem service (Elton and Miller, 1954). Freshwater ecosystem are considered as one of the most essential natural resources for all the living 
organisms on the earth. The various freshwater ecosystem include,rivers, ponds, etc. Now a days, the significant increase in population as a result of the amount of disposal has created a major problem for its disposal. As a result it has increased the level of water pollution and as a result the ponds have been given euteutrophication. Among, further risks to the development of ponds under the present study are the process and the increase in human settlement near the pond. It has deteriorated the health of those ponds owing to the discharge of untreated sewage water from the nearby settlements into them. Therefore, water quality assessment is essential for controlling surface water pollution (Raveen, Daniel, 2010). Many studies have found that phytoplankton and zooplankton can be used as indicators of water pollution (Jonnalagadda Mhere, 2001) and (Ravikumar, et al. 2011). When aquatic systems are considered, plankton are proven to be significant because changes in the immediate response of plankton plankton (Thakur et. al. 2013 ) and (Chattopadhyay, 2014). The rate of growth and development of plankton depends on various biological as well as biological factors such as light, temperature, available nutrients, oxygen concentration, pH, etc (Dhar et. al. 2012) . The phytoplanktons from the basic trophic level and are succeeded by the zooplankton as the next level (Shanthala et. al 2008) and (Malik. et. al. 2013). The population of zooplankton is influenced by the physicochemical characteristics of the body of water and it also changes according to the changes of the variation in the seasons (Hulyal Kaliwal, 2008) and (Kudari Kanamadi, 2008). Analysis of both qualitative and quantitave such indicative organs leads to the detection of one contaminant at a time as apposed to physical processes, resulting in a helpful alternative for consolidating the effects of multiple contaminants. In addition, indicators and other systems have been used to determine the current status of various reservoirs. The bio-monitoring process has become an essential part of the study of water pollution and contributes extensively to the submitted research on water quality determination (Malik et. al 2013). The ponds under the present study are in the process of development and are at greater risk of increasing human settlement around the pond. It has damaged the health of this pond due to incessant discharge untreated sewage from nearby settlement enters them. Thus, assessment of water quality in these ponds has become extremely important in controlling its water pollution. The study was conducted to assess the water quality of three ponds (Pond- 1, Pond- 2 Pond- 3) in Hooghly district of West Bengal, India by evaluating physicochemical and biological parameters.

\section{Study Area :-}

The current study deals with the assessment of water quality in three ponds of Hooghly district in India. The region has a tropical savanna climate with high temperature. The annual mean temperature is $26.8^{\circ} \mathrm{C}$, although monthly mean temperatures range from $16{ }^{\circ} \mathrm{C}$ to $33{ }^{\circ} \mathrm{C}$ and maximum temperature in the region often exceed $38{ }^{\circ} \mathrm{C}$. Maximum rainfall occurs during the Monsoon in August and the average annual total above $1500 \mathrm{~mm}$. Moderate North-West 
to North-East winds prevails for most of the year with a high frequency of calms. Summer is dominated by strong South-West Monsoon winds. Winters are comfortable with temperatures lying between $11^{\circ} \mathrm{C}$ to $17^{\circ} \mathrm{C}$. The following is a brief description of the three ponds that have been considered for the study.

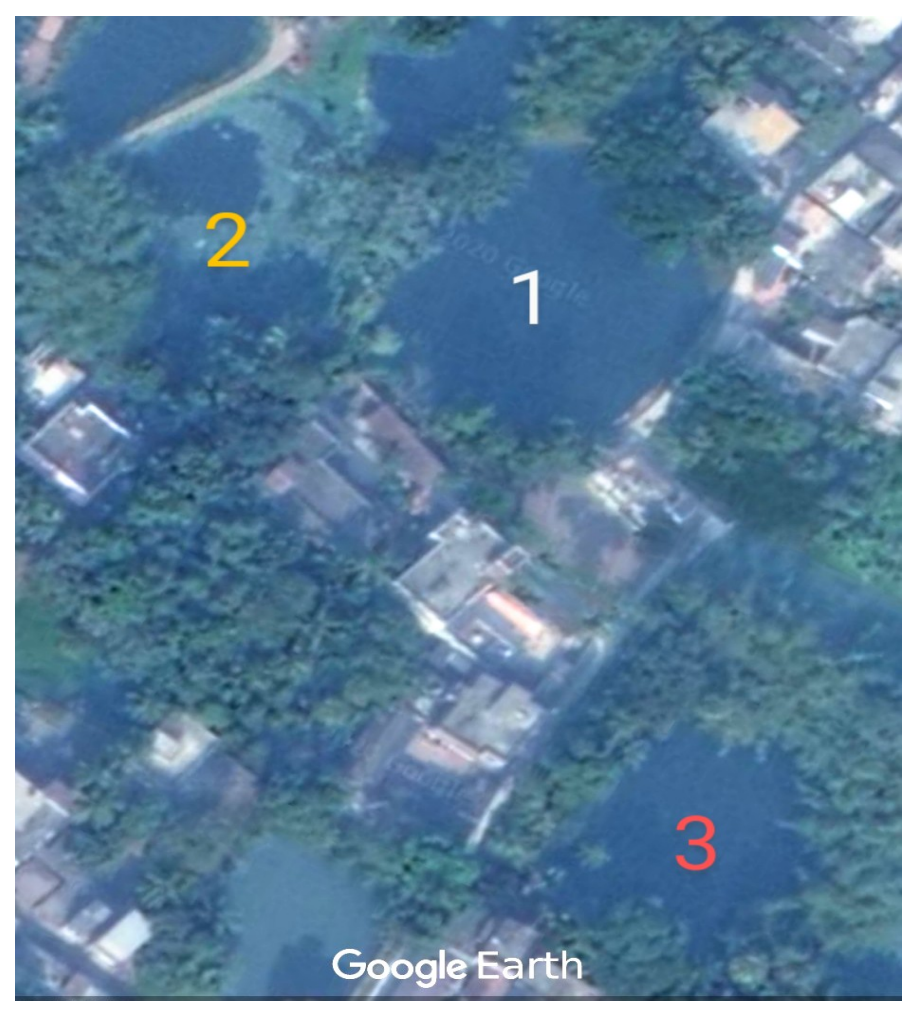

Figure 1: Study area (Pond- 1, Pond- 2, Pond- 3)

\subsection{Pond:- 1}

Pond- 1 is situated between $22^{\circ} 47^{\prime} 13^{\prime \prime} \mathrm{N}$ to $22^{\circ} 47^{\prime} 14^{\prime \prime} \mathrm{N}$ and $87^{\circ} 57^{\prime} 49^{\prime \prime} \mathrm{E}$. Pond1 has a bound length of $151 \mathrm{~m}$. This pond is almost round in shape and outlets of small house. Houses and slums on both sides of pond- 1 are decorated and receive untreated household discharges from residential area. The house wastes are diverted to this pond and it is the main source of pollution. 


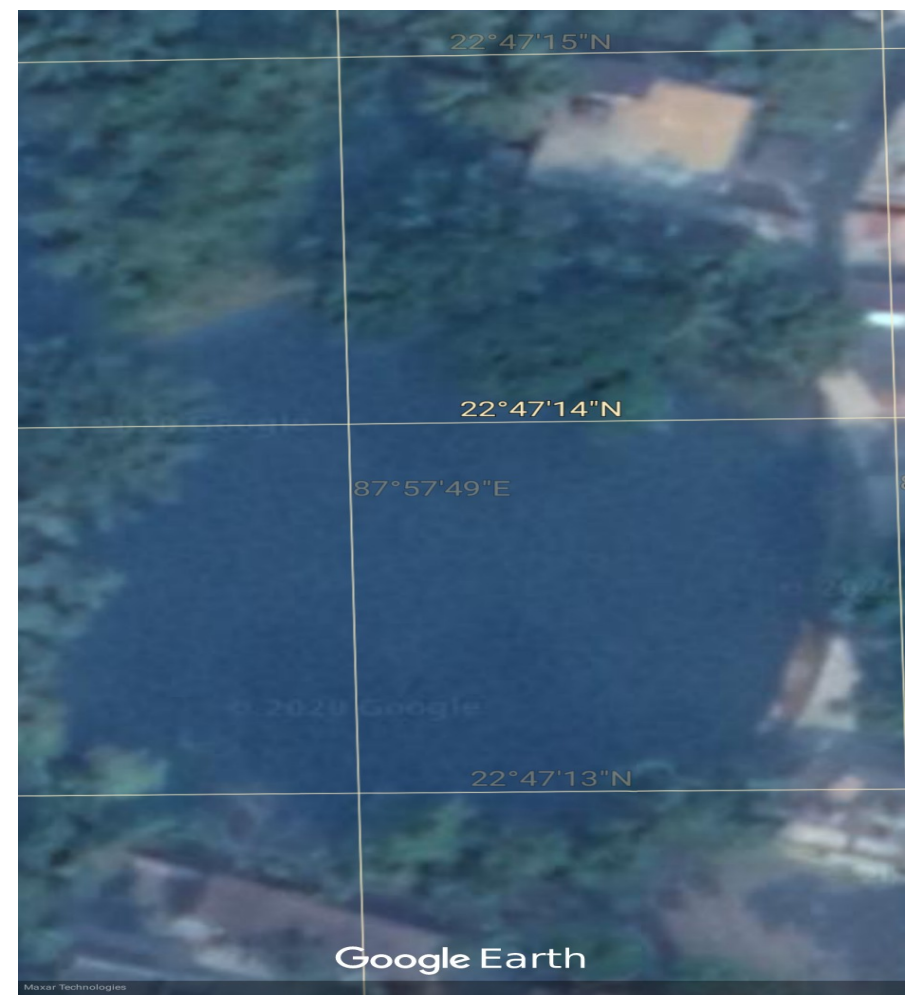

Figure 2: Pond - 1

\subsection{Pond:- 2}

Pond- 2 is situated between $87^{\circ} 57^{\prime} 48^{\prime \prime} \mathrm{E}$ and $22^{\circ} 47^{\prime} 13^{\prime \prime} \mathrm{N}$ to $22^{\circ} 47^{\prime} 14^{\prime \prime} \mathrm{N}$. Pond2 has a bound length of $129 \mathrm{~m}$. This pond is almost rectangular in shape and outlets of small house. Houses and slums on both sides of pond- 2 are decorated and receive untreated household discharges from residential area. The house wastes are diverted to this pond and it is the main source of pollution. 


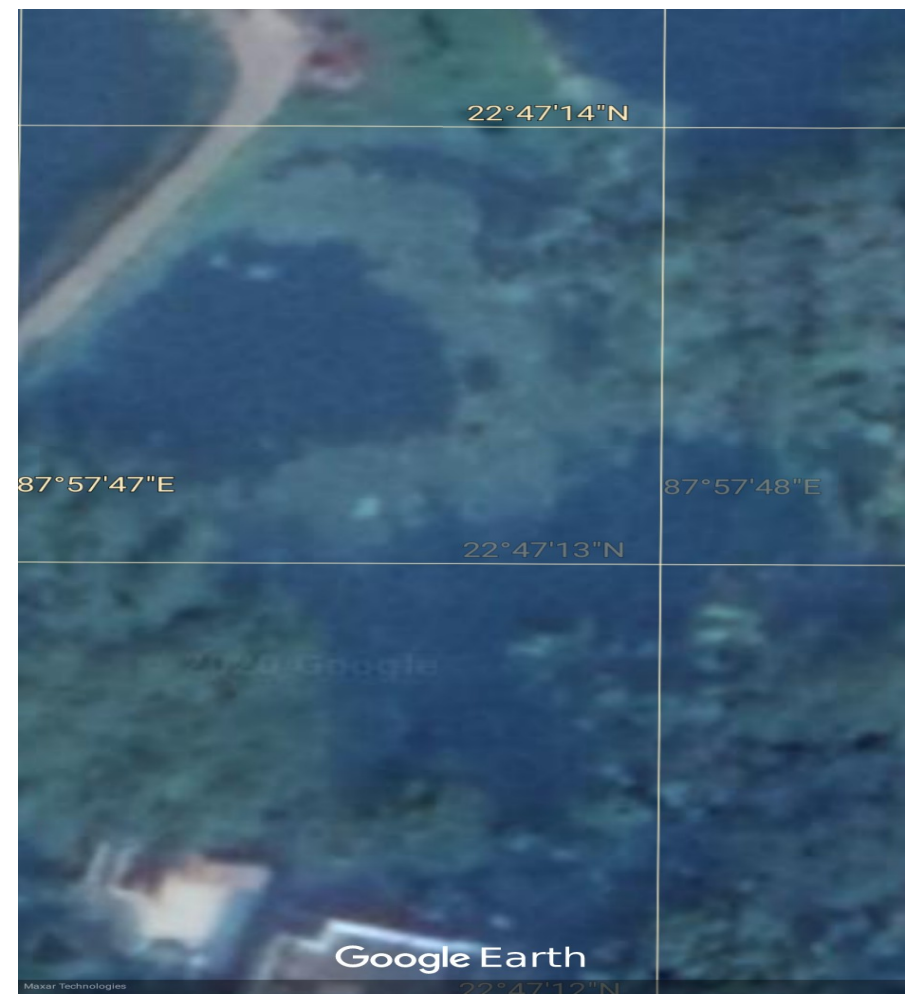

Figure 3: Pond - 2

\subsection{Pond:- 3}

Pond- 3 is situated between $87^{\circ} 57^{\prime} 51^{\prime \prime} \mathrm{E}$ and $22^{\circ} 47^{\prime} 11^{\prime \prime} N$. Pond- 3 has a bound length of $124 \mathrm{~m}$. This pond is almost round in shape and outlets of small house. Houses and slums on both sides of pond- 3 are decorated and receive untreated household discharges from residential area. The house wastes are diverted to this pond and it is the main source of pollution. 


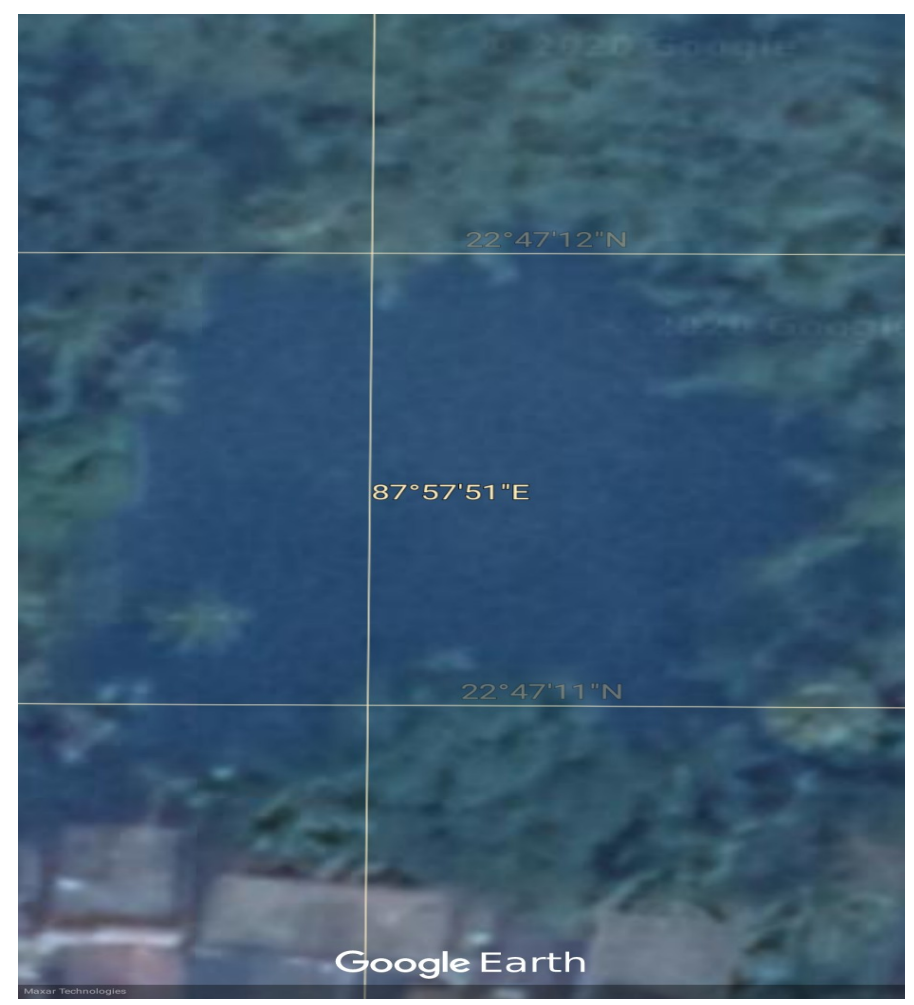

Figure 4: Pond - 3

\section{Material and Method :-}

The water sampling was done during the Summer and rainy season for two months from 28th March to 28th July, 2020. Sampling points such as washing, bathing, cattle's stool and urine discharges etc, occurring on the shores of the ponds were carefully considered and distributed evenly over the pond area. Samples were collected from the same point on every time.

\section{Physicochemical Analysis :-}

Surface water was collected from the pond and stored in PET bottles. The bottles were washed using sampling water and water was collected at and around the collection points with minimal disturbance. The bottles were filled with due care so that no debris would fall and DO or BOD level of the water would not be disturbed. The collected samples were then labelled and transferred to the laboratory, of Shyampur High School, Hooghly, West Bengal, and Ramakrishna Mission Vivekananda Centenary College, Rahara, Kolkata- 700118, for further analysis. The pond water quality was assessed by characterizing physicochem- 
ical parameters like pH, Electrical Conductivity (EC), Total dissolved oxygen, Total dissolved solids (TDS), Calcium, Chlorides, Bromides, Phosphates, Nitrates, Nitrites.

\section{Biological Analysis :-}

Plankton nets made out of blotting silk with wide thick bottles were used to collect the plankton. The net is conical and diameter of the mouth is $20 \mathrm{~cm}$. The 50 micrometer and 150 micrometer nets were used to collect the samples with a slow and steady horizontal motion the nets were carried to a depth about $0.5 \mathrm{~m}$ below the surface of the pond water. The filtrated water was then collected $200 \mathrm{ml}$ capacity PET bottles. These bottles were washed in sample water before sample collection. Then these bottles are then transferred to the laboratory, Shyampur High School, Hooghly, West Bengal, and Ramakrishna Mission Vivekananda Centenary College, Rahara, Kolkata- 700118, for further analysis. Within 24 hours, $5 \mathrm{ml}$ of $4 \%$ formalin solution was added to each $200 \mathrm{ml}$ bottle. Static samples were stored at room temperature until further analysis. Approximately $4 \mathrm{ml}$ of 10x, 40x from each sample were taken and monitored under a Compound Microscope.

\section{Plankton Diversity Index Calculation :-}

The indicators were diversity and dominance index of the identified plankton species. Diversity index was based on Shannon and Wiener index with the following formula as shown in Equation- 1

$$
H^{\prime}=\sum_{i=1}^{n} p i l n p i
$$

Description: $\mathrm{H}^{\prime}=$ Shannon-Wiener diversity index; $\mathrm{pi}=\mathrm{ni} / \mathrm{N}$; ni $=$ number of individual species- ith; $\mathrm{N}=$ total number of individuals.

Dominance index was determined using for following formula as shown in Equation2

$$
D=\sum_{i=1}^{s}\left(\frac{n i}{N}\right)^{2}
$$

Description: $\mathrm{D}=$ Simpson dominance index; $\mathrm{ni}=$ number of individual- ith; $\mathrm{N}=$ total number of individuals; $\mathrm{S}=$ number of genera.

\section{Results and Discussion :-}

The average values of water quality parameters in the study ponds are shown in Table 1, 2 and 3. Biological Oxygen Demand (BOD) refers to the amount 


\begin{tabular}{|c|c|c|c|c|}
\hline Topic & Maximum & Minimum & Range & Mean \\
\hline Temperature & 33.3 & 32.5 & 0.8 & 32.9 \\
\hline pH & 8.3 & 7.8 & 0.5 & 8.05 \\
\hline TDS & 497.00 & 428.00 & 69.00 & 462.5 \\
\hline EC & 902.00 & 857.00 & 45.00 & 879.5 \\
\hline DO & 6.03 & 4.23 & 1.8 & 5.13 \\
\hline Phosphates & 0.8 & 0.25 & 0.55 & 0.52 \\
\hline Nitrites & 0.65 & 0.21 & 0.44 & 0.43 \\
\hline Nitrates & 1.0 & 0.4 & 0.6 & 0.7 \\
\hline Chlorides & 1.5 & 0.6 & 0.9 & 1.05 \\
\hline Calcium & 10 & 5.8 & 4.2 & 7.9 \\
\hline Bromides & 2.4 & 1.3 & 1.1 & 1.85 \\
\hline
\end{tabular}

Table 1: Mean values of water quality (Physicochemical) parameters of pond-1

of oxygen needed by an organism to oxidized all organic matter and indirectly the oxygen required for respiration. BOD levels to determine contamination levels. The higher BOD values indicate higher amount of organic matter decomposition in the pond. BOD shows an inverse relationship with the values of DO taking dissolved oxygen for the process of digestion. At the time of the survey, the level of DO in pond- 1 , pond- 2 , pond- 3 were $5.13 \mathrm{mg} / \mathrm{L}, 5.12 \mathrm{mg} / \mathrm{L}$, $5.15 \mathrm{mg} / \mathrm{L}$. The highest value observed was $5.15 \mathrm{mg} / \mathrm{L}$ and the lowest value obtained was $5.12 \mathrm{mg} / \mathrm{L}$. The gradual decrease in the level of dissolved oxygen refers to declining quality of the pond water and the increasing inadequacy for its internal use. The nitrates found in Pond-1, Pond- 2 and Pond- 3 are $0.7 \mathrm{mg} / \mathrm{L}, 0.55 \mathrm{mg} / \mathrm{L}, 0.35 \mathrm{mg} / \mathrm{L}$ respectively in $\mathrm{mg} / \mathrm{L}$. High levels of nitrates and phosphates in water bodies indicate high levels of eutrophication in three ponds (Thakur et. al. 2013). These nitrates and phosphates prove to be the key to highly algal blooms in water bodies, resulting in increased levels of contamination. The main sources of phosphate are detergents and soaps used for house cleaning, bathing and clothes cleaning, while nitrates are found in the discharge of treated domestic sewage water. Algal blooms can be observed in values starting from $0.03 \mathrm{mg} / \mathrm{L}$ of phosphate in water. The greenish-blue waters observed by plain eye during sample collecting support the explanation for the excessive algal growth in these freshwater ponds. All investigations have shown that ponds show very high levels of TDS and alkalinity. The reason behind this can be attributed to human influence and instability (Sudha et. al 2013). The values obtained for pond- 1, pond- 2, pond- 3 for TDS are 462.5ppm, 476.5ppm, $324.5 \mathrm{ppm}$ respectively in ppm. Alkalinity values were also high and therefore, indicated pollution in the ponds (Debels et. al. 2005). Pond had a maximum of $2.85 \mathrm{mg} / \mathrm{L}$ of water chlorides. Such higher levels of chloride in water are a confirmation of the presence of eutrophication in the body of water (Vutukuru et. al 2012). Chloride levels are higher due to the discharge of heavy domestic sewage into the ponds. 


\begin{tabular}{|c|c|c|c|c|}
\hline Topic & Maximum & Minimum & Range & Mean \\
\hline Temperature & 36.5 & 35.8 & 0.7 & 36.1 \\
\hline pH & 8.2 & 7.3 & 0.9 & 7.75 \\
\hline TDS & 502.00 & 451.00 & 51.00 & 476.5 \\
\hline EC & 946.00 & 903.00 & 43.00 & 924.5 \\
\hline DO & 6.02 & 4.23 & 1.79 & 5.12 \\
\hline Phosphates & 1.5 & 0.5 & 1.0 & 1.00 \\
\hline Nitrites & 2.05 & 0.73 & 1.32 & 1.39 \\
\hline Nitrates & 0.8 & 0.3 & 0.5 & 0.55 \\
\hline Chlorides & 3.5 & 2.2 & 1.3 & 2.85 \\
\hline Calcium & 10 & 5.6 & 4.4 & 7.8 \\
\hline Bromides & 5.5 & 4.1 & 1.4 & 4.8 \\
\hline
\end{tabular}

Table 2: Mean values of water quality (Physicochemical) parameters of pond-2

\begin{tabular}{|c|c|c|c|c|}
\hline Topic & Maximum & Minimum & Range & Mean \\
\hline Temperature & 37.3 & 36.2 & 1.1 & 36.75 \\
\hline pH & 8.2 & 7.5 & 0.7 & 7.85 \\
\hline TDS & 365.00 & 284.00 & 81 & 324.5 \\
\hline EC & 638.00 & 540.00 & 98 & 589.00 \\
\hline DO & 6.03 & 4.27 & 1.76 & 5.15 \\
\hline Phosphates & 0.7 & 0.25 & 0.45 & 0.47 \\
\hline Nitrites & 0.55 & 0.18 & 0.37 & 0.36 \\
\hline Nitrates & 0.5 & 0.2 & 0.3 & 0.35 \\
\hline Chlorides & 1.2 & 0.6 & 0.6 & 0.9 \\
\hline Calcium & 10 & 5.5 & 4.5 & 7.75 \\
\hline Bromides & 2.2 & 1.2 & 1.0 & 1.7 \\
\hline
\end{tabular}

Table 3: Mean values of water quality (Physicochemical) parameters of pond-3 


\begin{tabular}{|c|c|c|c|}
\hline Species & Pond - 1 & Pond - 2 & Pond - 3 \\
\hline Anabena & 1 & 1 & 0 \\
\hline Chlorella & 0 & 0 & 2 \\
\hline Closterium & 1 & 1 & 0 \\
\hline Euglena & 4 & 4 & 4 \\
\hline Flagilaria & 0 & 1 & 0 \\
\hline Navicula & 2 & 2 & 2 \\
\hline Nitzschia & 0 & 2 & 2 \\
\hline Oscillatoria & 2 & 2 & 2 \\
\hline Phacus & 1 & 1 & 1 \\
\hline Total & 11 & 14 & 13 \\
\hline $\begin{array}{c}\text { Shannon } \\
\text { diversity } \\
\text { index (H) }\end{array}$ & 1.629 & 1.917 & 1.677 \\
\hline \multicolumn{2}{|l}{} & & \\
\hline
\end{tabular}

Table 4: Species Index Value for The Study Three Ponds

\section{Conclusion :-}

Phytoplankton is a type of microscopic plankton capable of photosynthesis that found an essential element of the aquatic ecosystem, seas, and freshwater, and pond water ecosystem. Phytoplankton can be range in size and shape, and they are photosheshesizing the autotrophic organism, they live in the open water of sunlight. Although each organism can be seen as a microscopic, adequate number, Phytoplankton can be seen as colored patches of water, or two streams meet, due to the presence of chlorophyll. Phytoplankton is often cultured to support the pond ecosystem and after the Precambrian era, critical for control of carbon dioxide and oxygen levels in the Earth's atmosphere. Indeed, it is estimated that Phytoplankton is responsible for $85 \%$ of oxygen in the atmosphere. The aquatic environment is an area controlled by the changes in factors such as light, heat, humidity and contamination of various effluents in the water body. The results from this study indicated that the increased level of temperature led to increased water evaporation, followed by rich nutrients and an elevated level of zooplankton abundance in the lake during the summer season, whereas zooplankton falls during the monsoon due to dilution of the pond by rainfall. Therefore, the present study suggests that the water temperature can positively support the population diversity of zooplankton with the evidence from high degree of positive correlation between temperature, total dissolved solids and plankton density. However, further studies are warranted on the continuous monitoring of these ponds ecosystem to know the future impact of climate change on distribution of zooplankton. Contamination of water through domestic sewage has also been noticed which gradually reduces the productivity status of these ponds. Proper biological and chemical treatments of domestic sewage need to be done before discharge to the ponds for long run sustainable resources. To sum up, the present observations are limited to the quantitative observation 
from the three urban ponds, though it provides useful information on composition and ecology of plankton. The Pond -2 has low dissolved oxygen (5.12 $\mathrm{mg} / \mathrm{L})$ and TDS (476.50ppm) and phosphate $(1.00 \mathrm{mg} / \mathrm{L})$, which may be mainly due to the increased population growth in the surroundings, encroachments in and around the pond, leading to pollution of the pond through discharge of untreated domestic sewage and domestic wastewater. The inlet of sewage might increase the nutrient levels considerably in the pond. Pond -3 shows high dissolved oxygen $(5.15 \mathrm{mg} / \mathrm{L})$ and TDS $(324.50 \mathrm{ppm})$ and phosphates $(0.47 \mathrm{mg} / \mathrm{L})$ when compared with Pond -2, this may be due to less anthropogenic influence and low urbanization of the area around it. The presence of pollution indicating genera in those three ponds like Navicula, Phacus, Oscillatoria, Anabaena, Euglena, Rotifera, etc. signifies the degraded quality of the ponds at present. The physicochemical and biological characters change in the lentic ecosystem due to the discharge of wastes, which increase the concentration of different chemicals (Pal et al. 2014). From the present study, it is apparent that a respectable number of phytoplankton species thrived in these wastewater-fed ponds, when added to these ponds harbor different floating and marginal macrophytes. That means this urban wastewater, which contains several nutrients, not only enriches the phytoplankton diversity and abundances in these ponds but also is helpful for pisciculture practices and it will surely improve the local economy. The present basic information of the plankton distribution and abundance would form a useful tool for further ecological assessment and monitoring of the ecosystem of these three ponds in Hooghly, West Bengal.

\section{Acknowledgement :-}

I am thankful to Swami Kamalasthananda Maharaj, Swami Vedanuragananda Maharaj of RKMVC College and Suparna Maity of Shyampur High School for giving me some ardent help and suggestions during the preparation of this manuscript.

\section{References :-}

[1] Bureau of Indian Standards (BIS) (1998) Drinking water specifications (revised 2003), IS: 10500.

[2] Chattopadhyay, C. (2014, June). Polyphenolics and energy content in phytoplankton: evidence from a freshwater lake. In Proceedings of the Zoological Society (Vol. 67, No. 1, pp. 18-27). Springer India.

[3] Cude, C. G. (2001). Oregon water quality index a tool for evaluating water quality management effectiveness 1. JAWRA Journal of the American Water Resources Association, 37(1), 125-137.

[4] Debels, P., Figueroa, R., Urrutia, R., Barra, R., Niell, X. (2005). Evaluation of water quality in the Chillán River (Central Chile) using physicochemical parameters and a modified water quality index. Environmental monitoring and 
assessment, 110(1-3), 301-322.

[5] Dhar, J., Baghel, R. S., Sharma, A. K. (2012). Role of instant nutrient replenishment on plankton dynamics with diffusion in a closed system: a pattern formation. Applied Mathematics and Computation, 218(17), 8925-8936.

[6] Dojlido, J., Raniszewski, J., Woyciechowska, J. (1994). Water quality index applied to rivers in the Vistula river basin in Poland. Environmental monitoring and assessment, 33(1), 33-42.

[7] Elton, C. S., Miller, R. S. (1954). The ecological survey of animal communities: with a practical system of classifying habitats by structural characters. Journal of Ecology, 42(2), 460-496.

[8] Hulyal, S. B., Kaliwal, B. B. (2008). Water quality assessment of Almatti Reservoir of Bijapur (Karnataka State, India) with special reference to zooplankton. Environmental monitoring and assessment, 139(1-3), 299-306.

[9] Jonnalagadda, S. B., Mhere, G. (2001). Water quality of the Odzi River in the eastern highlands of Zimbabwe. Water research, 35(10), 2371-2376.

[10] Kannel, P. R., Lee, S., Lee, Y. S., Kanel, S. R., Khan, S. P. (2007). Application of water quality indices and dissolved oxygen as indicators for river water classification and urban impact assessment. Environmental monitoring and assessment, 132(1-3), 93-110.

[11] Kudari, V. A., Kanamadi, R. D. (2008). Impact of changed trophic status on the zooplankton composition in six water bodies of Dharwad district, Karnataka state (South India). Environmental monitoring and assessment, 144(1-3), 301-313.

[12] Malik, N., Biswas, A. K., Raju, C. B. (2013). Plankton as an indicator of heavy metal pollution in a freshwater reservoir of Madhya Pradesh, India. Bulletin of environmental contamination and toxicology, 90(6), 725-729.

[13] Pandit, A. K., Yousuf, A. R. (2002). Trophic status of Kashmir Himalayan lakes as depicted by water chemistry. J Res Dev, 2, 1-12.

[14] Panigrahi, S. N., Nayak, B. B., Acharya, B. C. (2001). Planktonic algae as water pollution index of Maipura Estuary, East Coast of India. Journal of the Marine Biological Association of India, 43(1), 168-172.

[15] Rahman, I. M. M., Islam, M. M., Hossain, M. M., Hossain, M. S., Begum, Z. A., Chowdhury, D. A., ... Hasegawa, H. (2011). Stagnant surface water bodies (SSWBs) as an alternative water resource for the Chittagong metropolitan area of Bangladesh: physicochemical characterization in terms of water quality indices. Environmental monitoring and assessment, 173(1-4), 669-684.

[16] Raveen, R., Daniel, M. (2010). Spatial changes in water quality of urban lakes in Chennai (India)-a case study. Journal of environmental science engineering, 52(3), 259-264.

[17] Ravikumar, P., Mehmood, M. A., Somashekar, R. K. (2013). Water quality index to determine the surface water quality of Sankey tank and Mallathahalli lake, Bangalore urban district, Karnataka, India. Applied water science, 3(1), 247-261.

[18] Ravikumar, P., Venkatesharaju, K., Prakash, K. L., Somashekar, R. K. (2011). Geochemistry of groundwater and groundwater prospects evaluation, Anekal Taluk, Bangalore urban district, Karnataka, India. Environmental 
monitoring and assessment, 179(1-4), 93-112.

[19] Sudha, M. C., Ravichandran, S., Sakthivadivel, R. (2013). Water bodies protection index for assessing the sustainability status of lakes under the influence of urbanization: A case study of south Chennai, India. Environment, development and sustainability, 15(5), 1157-1171.

[20] Thakur, R. K., Jindal, R., Singh, U. B., Ahluwalia, A. S. (2013). Plankton diversity and water quality assessment of three freshwater lakes of Mandi (Himachal Pradesh, India) with special reference to planktonic indicators. Environmental monitoring and assessment, 185(10), 8355-8373.

[21] Vutukuru, S. S., Asadi, S. S., Vasantha, R. B. V. T., Raju, M. V. (2012). Plankton biodiversity as indicators of the ecological status of River Moosi, Hyderabad, India. International Journal of Earth Science and Engineering, 5(3), 587-592.

[22] Yao, S., Xue, B., Kong, D. (2010). Chronology and nutrients change in recent sediment of Taihu Lake, lower Changjiang River Basin, East China. Chinese Geographical Science, 20(3), 202-208.

[23] Yu, F. C., Fang, G. H., Ru, X. W. (2010). Eutrophication, health risk assessment and spatial analysis of water quality in Gucheng Lake, China. Environmental Earth Sciences, 59(8), 1741-1748. 


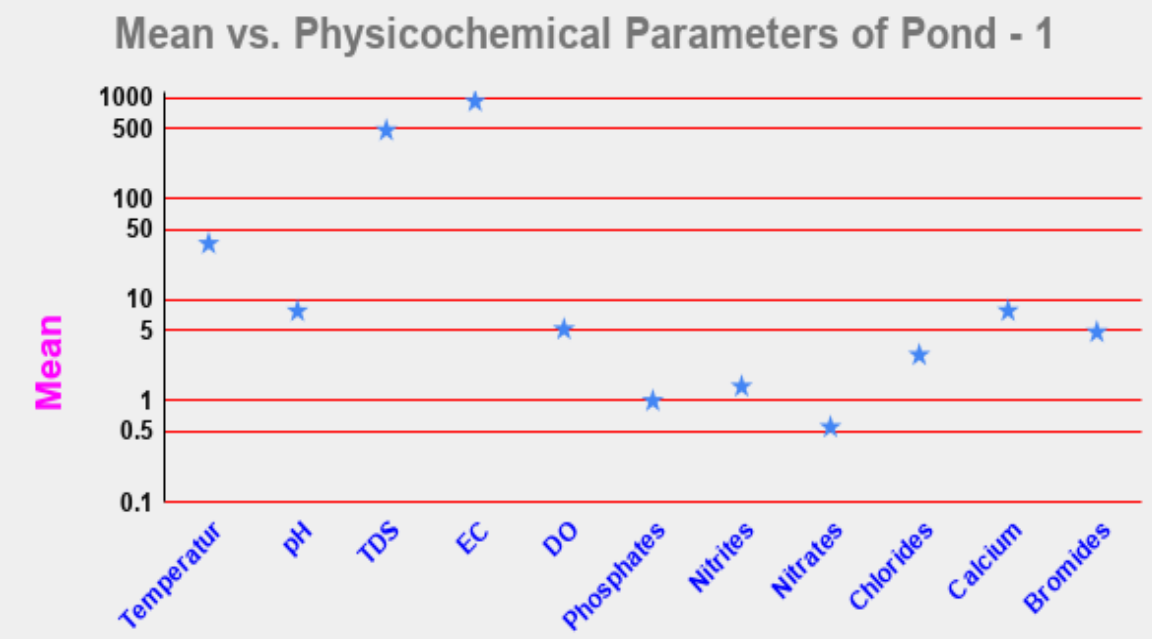

Physicochemical Parameters

Figure 5: Mean vs. Physicochemical Parameters of Pond - 1 (Graphical presentation)

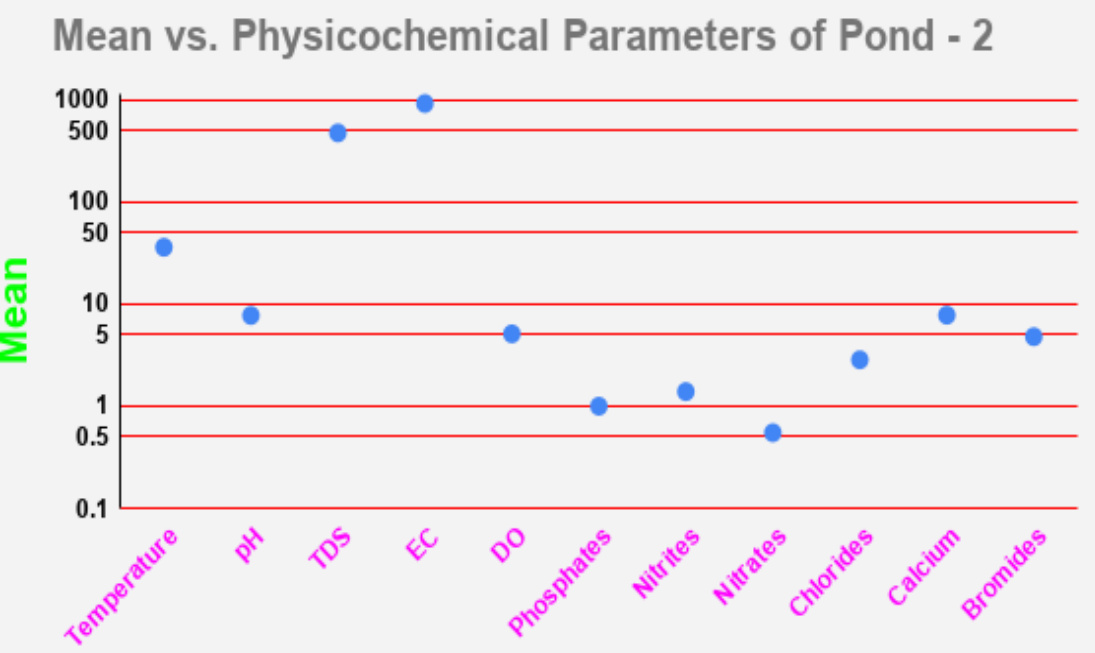

Physicochemical Parameters

Figure 6: Mean vs. Physicochemical Parameters of Pond - 2 (Graphical presentation) 


\section{Mean vs. Physicochemical Parameters of Pond - 3}

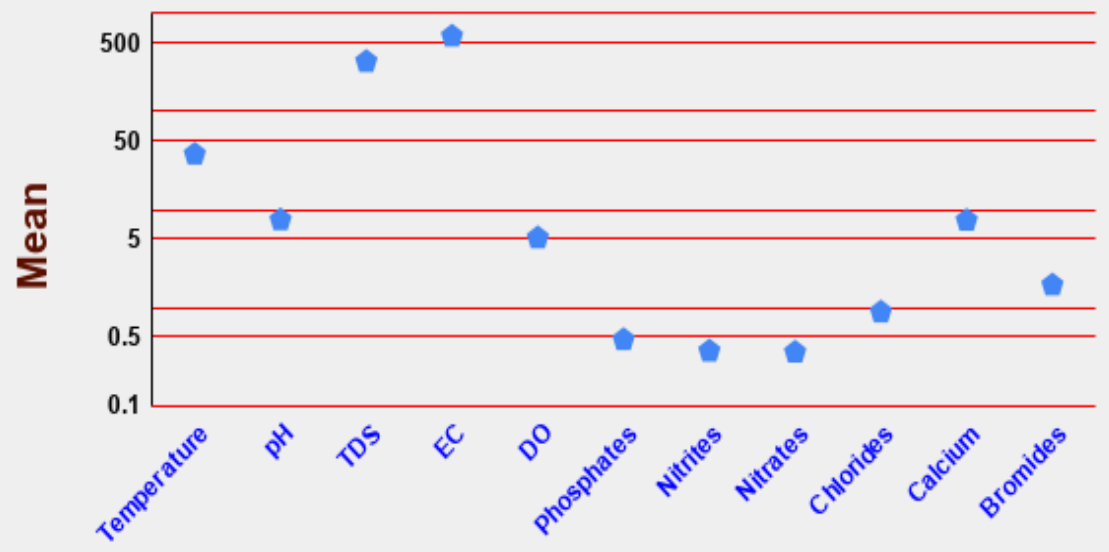

Physicochemical Parameters

Figure 7: Mean vs. Physicochemical Parameters of Pond - 3 (Graphical presentation) 
Figures

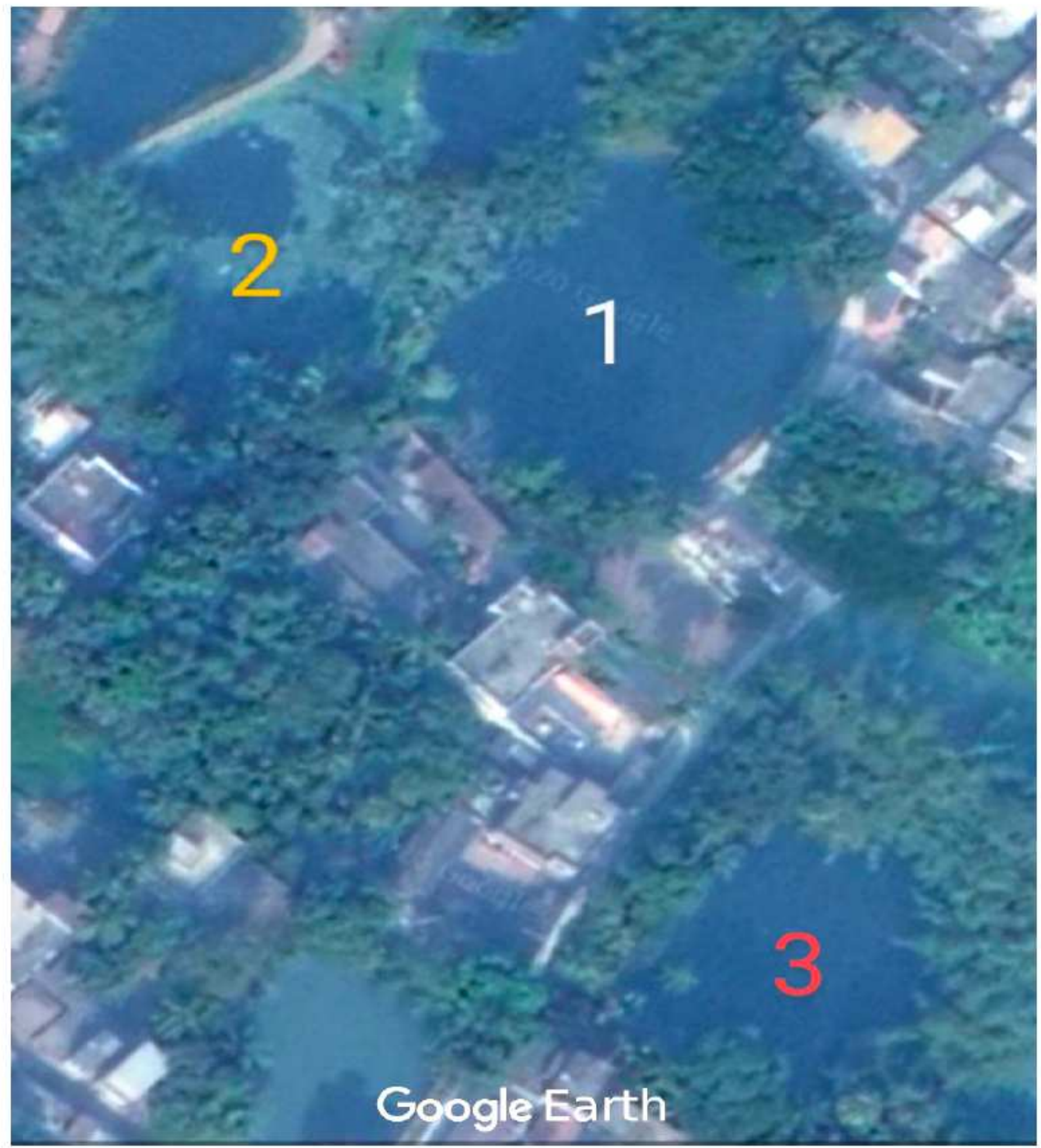

Figure 1

Study area (Pond- 1, Pond- 2, Pond- 3) 


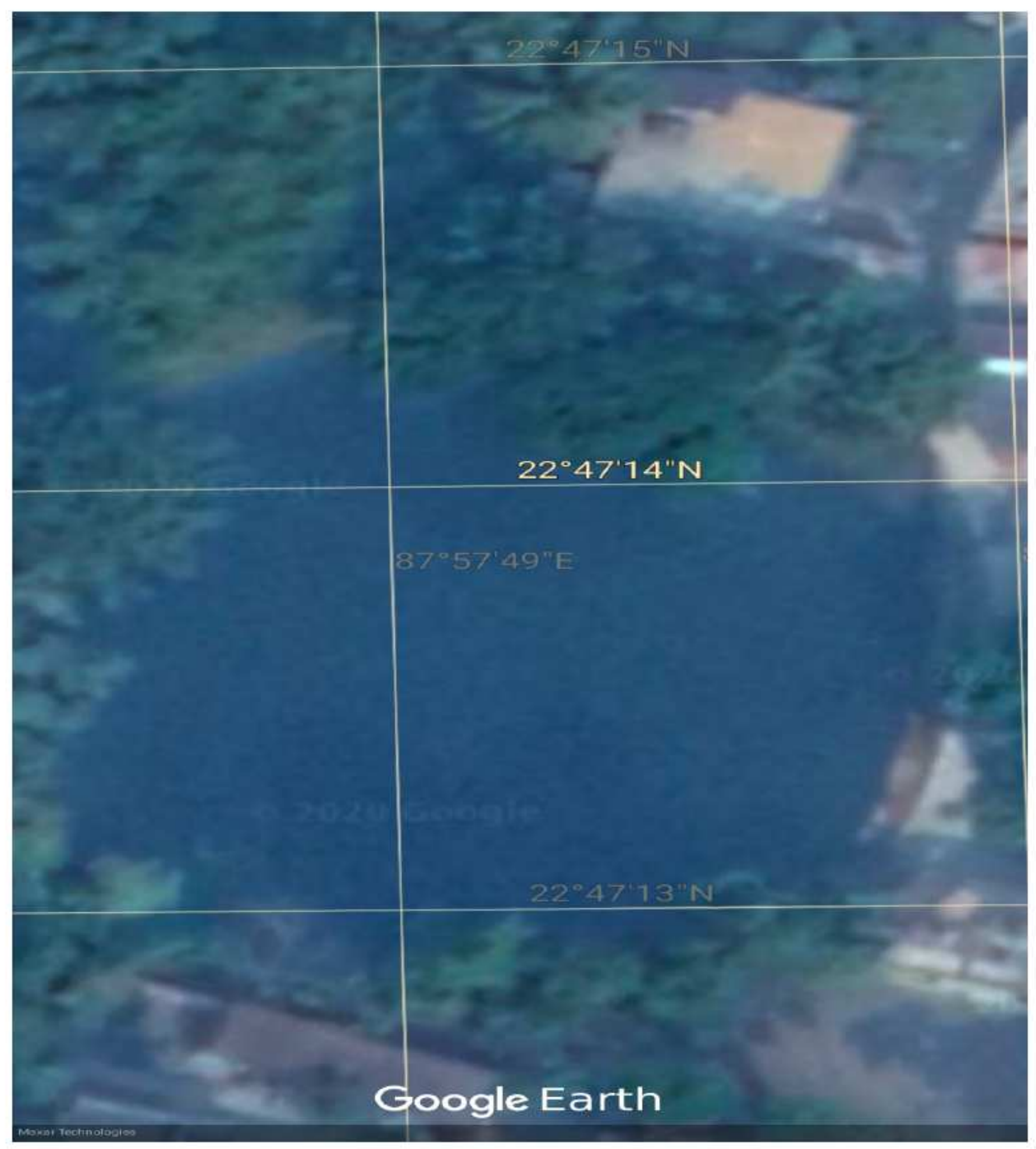

Figure 2

Pond - 1 


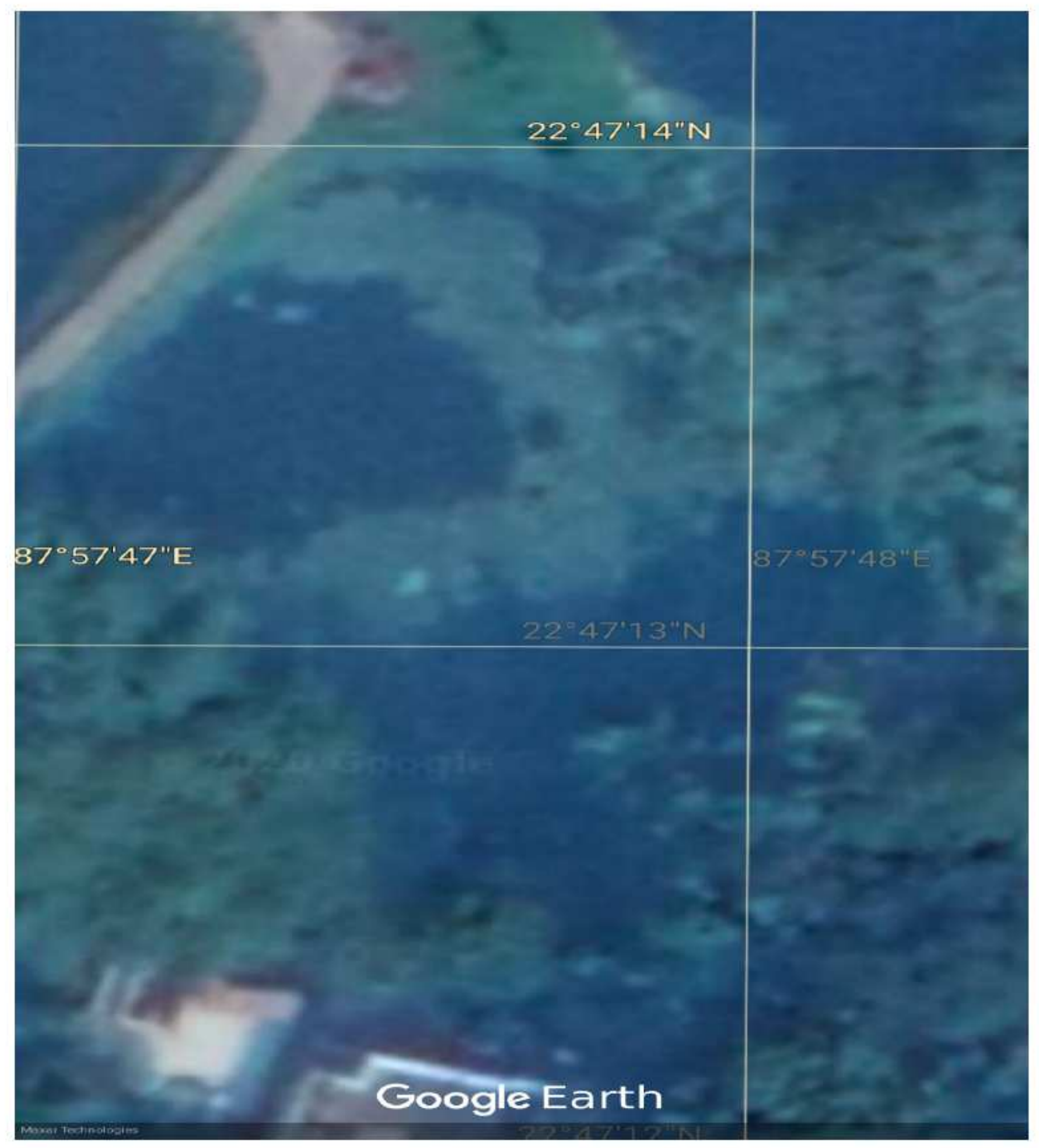

Figure 3

Pond - 2 


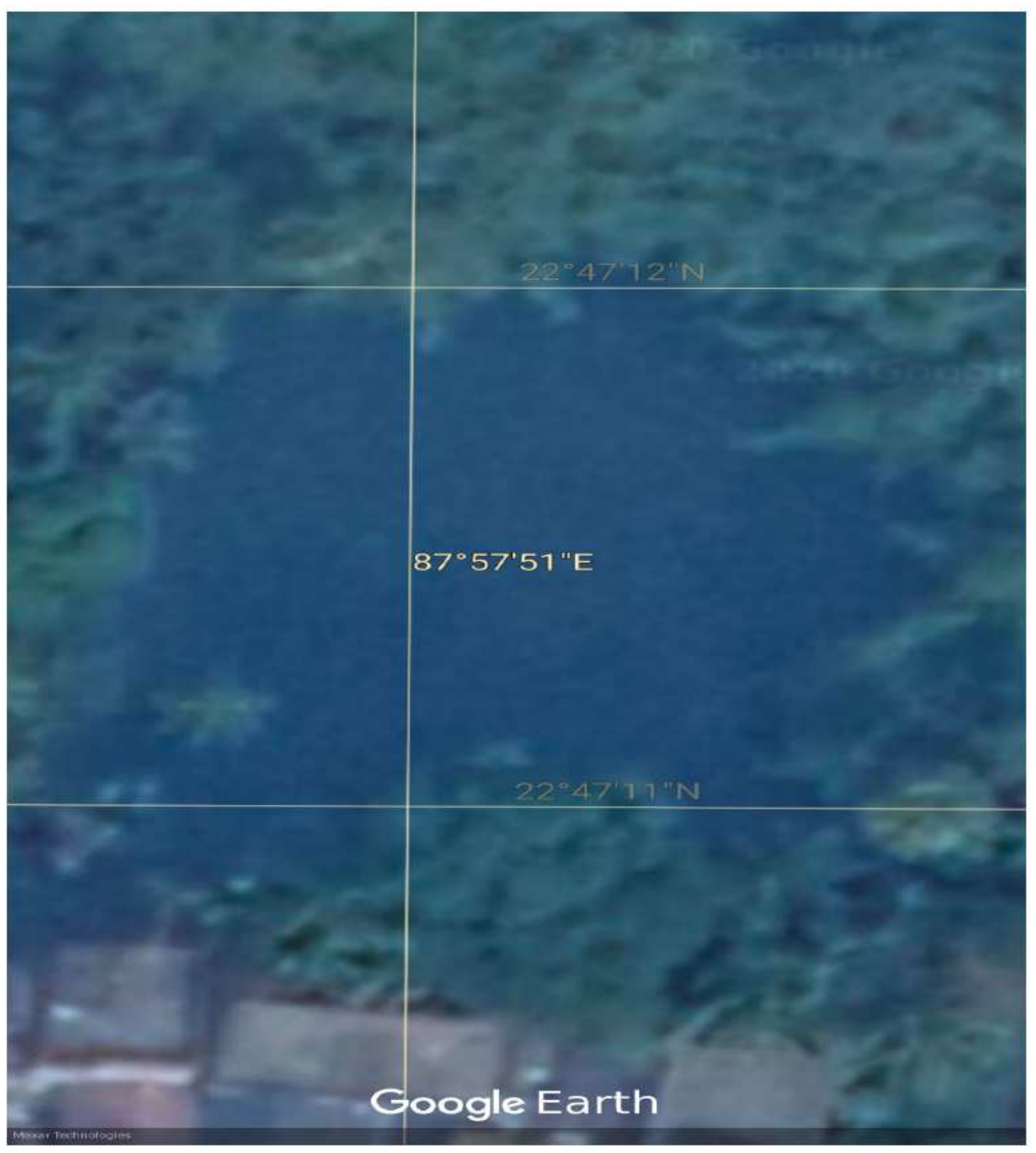

Figure 4

Pond - 3 


\section{Mean vs. Physicochemical Parameters of Pond - 1}

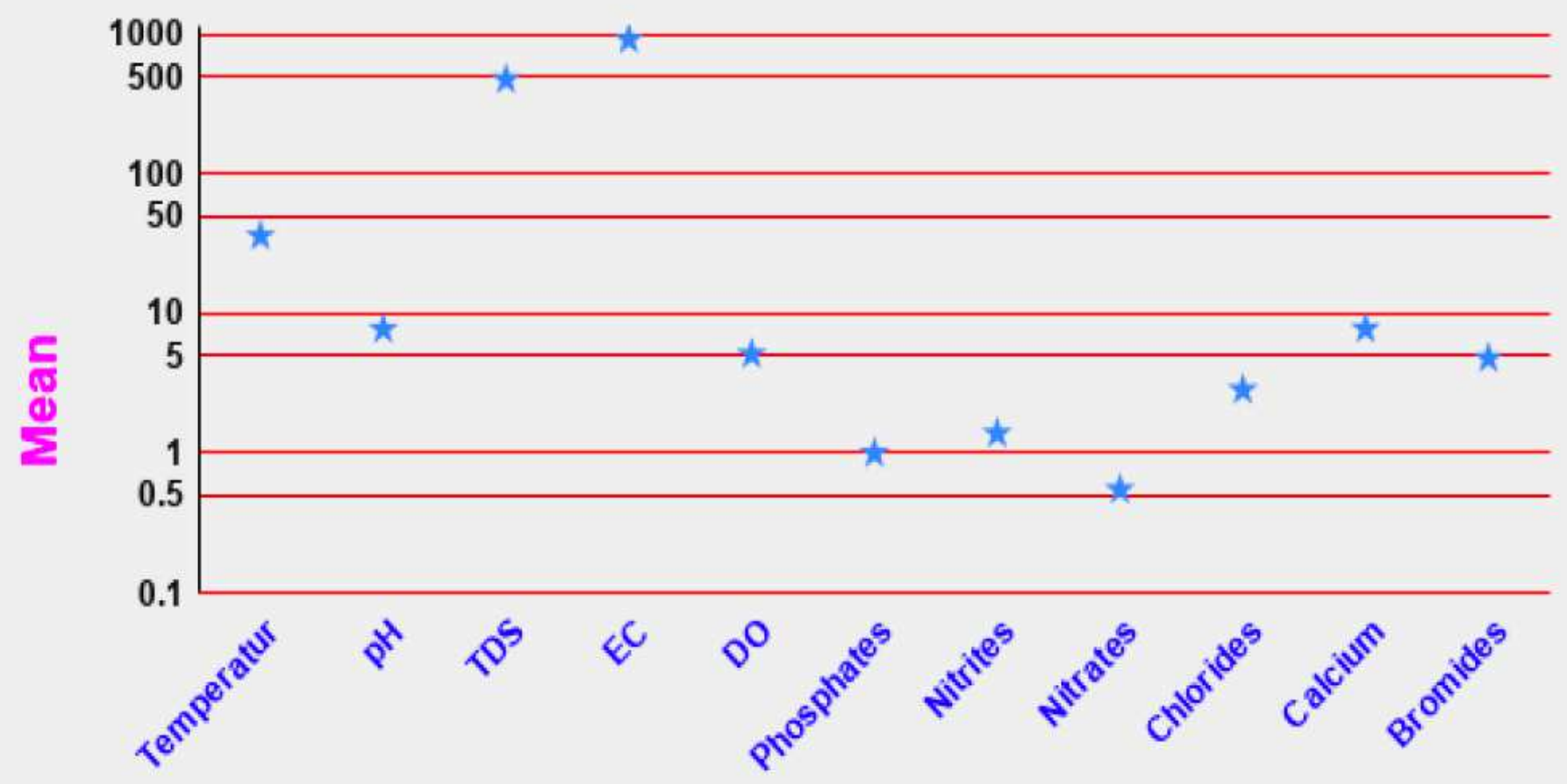

Physicochemical Parameters

Figure 5

Mean vs. Physicochemical Parameters of Pond - 1 (Graphical presentation) 


\section{Mean vs. Physicochemical Parameters of Pond - 2}

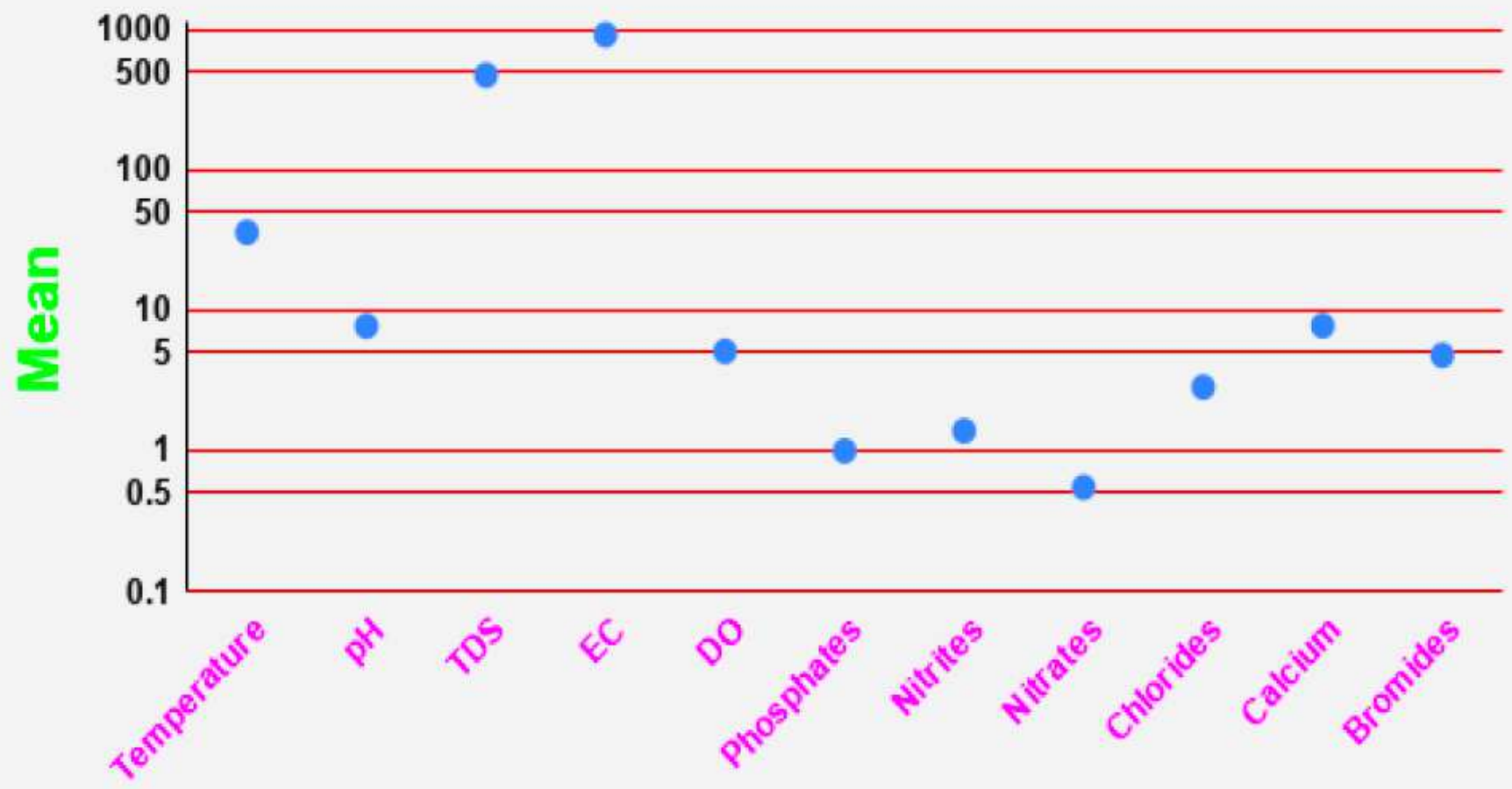

Physicochemical Parameters

Figure 6

Mean vs. Physicochemical Parameters of Pond - 2 (Graphical presentation) 


\section{Mean vs. Physicochemical Parameters of Pond - 3}

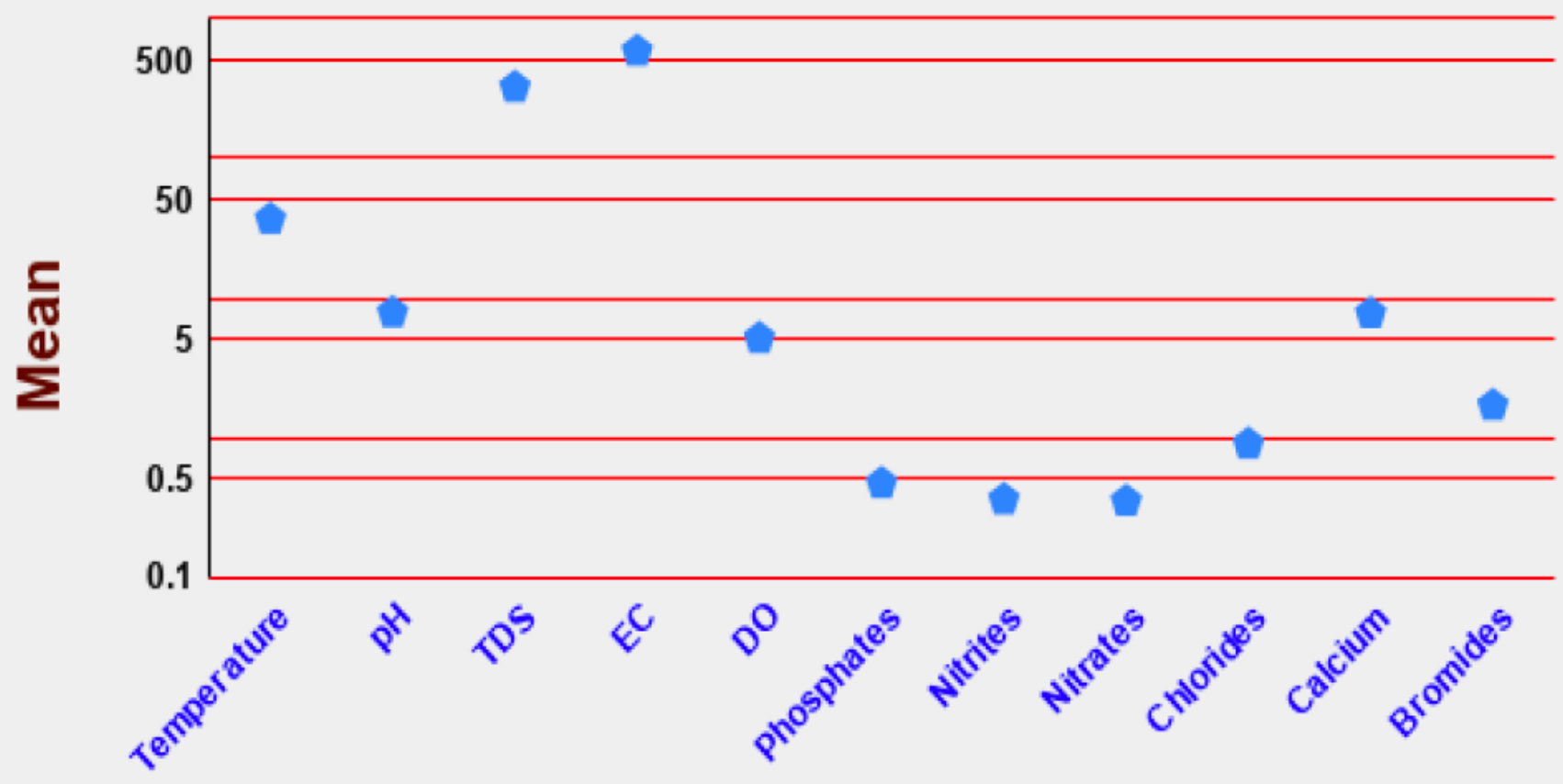

Physicochemical Parameters

Figure 7

Mean vs. Physicochemical Parameters of Pond - 3 (Graphical presentation) 